УДК 94 (37)

DOI: https://doi.org/10.33782/eminak2019.3(27).322

\title{
СЕКСУАЛЬНІСТЬ І ГУМОР У ДАВНЬОМУ РИМІ: ПЕРЕОСМИСЛЕННЯ ТА НОВІ ВАРІАЦІЇ
}

\author{
євгенія Федченко \\ Київський національний університет імені Тараса Шевченка (Київ, Україна) \\ e-mail: fedcenkoevgenia5@gmail.com \\ ORCID: https://orcid.org/0000-0001-9050-3338
}

У статті досліджується роль і місце сексуального гумору в житті Давнього Риму. На основі аналізу візуальних і писемних джерел було з'ясовано ставлення римлян до сміху та його вплив на формування суспільної думки. Прослідковано особливості сюжетного ряду та персоналії давньоримського сексуального гумору. Визначено головні функції, які виконували еротичні жарти: від релігійної до політичної. Це дозволило відкрити новий погляд на проблему та виявити взаємодію між гендерною ідентичністю та соціальним ступенем.

Ключові слова: Давній Рим, сексуальність, гумор, повсякденне життя, гендер

Сексуальний гумор - один із важливих предметів для наукових досліджень, адже протягом всіх історичних періодів він користувався неабиякою популярністю. Давні римляни не були винятком, оскільки поціновували та насолоджувались еротичними жартами, надаючи їм специфічного забарвлення.

Метою статті $є$ визначити місце та значення сексуального гумору в житті Давнього Риму. Аналізу піддається не тільки писемний, але й візуальний римський гумор: починаючи від каламбурів і закінчуючи різними формами публічних видовищних розваг. Відповідно до мети поставлені наступні завдання: виявити сюжетний ряд і персоналії давньоримського сексуального гумору; виділити основні функції непристойних римських жартів; проаналізувати ставлення римлян до сміху та вплив його на суспільну думку; простежити місця локацій гумористичних сексуальних зображень у Давньому Римі.

Проблематика давньоримського гумору знайшла відображення у дослідженнях багатьох американських і західноєвропейських вчених. Особливої уваги заслуговують праці Ентоні Корбейла і Мері Берд. Американець Е. Корбейл вперше розглядає римський гумор у політичному та соціальному контекстах 1 . Автор на прикладі промов давньоримського оратора Цицерона демонструє як суспільний гумор створює та забезпечує дотримання морально-етичних норм. Його послідовниця професор Кембриджського університету Мері Берд у своїй праці «Сміх у Давньому Римі: жарти, лоскіт і регіт» робить чудовий огляд класичних римських жартів та аналізує теорії гумору: від 3. Фройда до М. Бахтіна².

Значну увагу безпосередньо питанням сексуального давньоримського гумору приділяють Е. Річлін і Дж. Кларк. Ключовою й оригінальною є праця американського

\footnotetext{
1 Corbeill A. Controlling Laughter: Political Humor in the Late Roman Republic. Princeton: Princeton University Press, 1996. $251 \mathrm{p}$.

2 Beard M. Laughter in Ancient Rome: On Joking, Tickling, and Cracking. Berkeley; Los Angeles; London: University of California Press, 2014. 319 p.
} 
дослідника Дж. Кларка «Споглядаючи сміх: гумор, влада та трансгресія у римській візуальній культурі»3. Для написання цієї роботи він залучає велику кількість зображальних джерел (фрески, мозаїки, кераміку, статуї та епіграфіку), більшість 3 яких з Помпей і Геркуланума. Науковець акцентує увагу на соціальній функції візуального гумору. Інноваційним у роботі $є$ третій розділ, що присвячений винятково сексуальним жартам.

Дослідниця феміністичної течії Емі Річлен, прослідковує римську концепцію непристойності 4 . Вона аналізує значний спектр давньоримських джерел у світлі сучасної антропологічної теорії, підкреслюючи, що порушення римлянами моральноетичних норм встановлених державою для регулювання їх сексуального життя, надає цікавий матеріал для агресивного та доволі непристойного гумору в сатирі та пов'язаних із нею літературних формах. Річлен виокремлює також основні теми для жартів: імпотенція, потворство та старість.

Отже, майже всі перераховані дослідники зосереджували свою увагу на літературних джерелах упускаючи візуальні, а деякі образи та сюжети важливі для розуміння даної проблематики, розглянуті у кращому випадку фрагментарно. Тому, ми і зосередимо нашу увагу на них.

Дослідження грунтується на значній кількості візуальних і літературних першоджерел. Літературні джерела з даної тематики презентовані передусім латинськими авторами сатиричного жанру: Луцілієм, Марціалом, Ювеналом і Горацієм. Також важливими для роботи $є$ історичні праці: Геродот «Історія», Тіт Лівій «Історія від заснування міста», Тацит «Аннали». Біографічний жанр представлений Светонієм «Життя 12-ти Цезарів» і Плутархом «Порівняльні життєписи». Окрему роль відіграють епістолярні (Сенека «Листи до Луцілія», Горацій «Послання») та ліричні (Овідій, Катулл, Авл Гелій та інші) першоджерела. Потрібно зазначити і дрібні, гумористичні, часто досить непристойні епіграматичні твори, пов'язані з культом Пріапа. Найважливішими з їх зібрань є Corpus (чи Libellus) Priapeorum, відомий також, як Пріапічні пісні (Carmina priapea). Другу групу джерел дослідження становлять давньоримські візуальні пам'ятки - мозаїки, фрески, скульптури та предмети декоративноприкладного мистецтва.

В основі значної частини римського гумору лежить концепція «obscenity», тобто «непристойності». Якщо звертатись до етимології терміну «obscaenum» - «брудний», то він бере свої корені від латинського «scaena» («сцена, за кулісами») (Varro. De Ling. Lat. VII. 96). Тому не дивно, що непристойні зображення та слова сприймаються римлянами як комічне театральне видовище. Гумористичне використання «obscenity» також певною мірою пов'язано з апотропією. Оскільки велику кількість релігійних обрядів і святкувань (Triumphus (Тріумф), ludi Florales (ігри Флори) й інші), супроводжували непристойні жартівливі вірші та пісні (Mart. I.4.3, VII.8.9f, XI.15.11-13). У зв'язку з цим варто згадати Сатурналії - свято відзначене повною свободою слова між господарем і рабом та усіма громадянами (Hor. Sat. II.3, II.7.4, Ep. II.1, 139-146; Macrob. Sat. I.7.18ff; Sen. Apocol. VIII.2, Epist. XLVII.14; Plin. Epist. II.17.24. Varr. LL. VI,14; Ovid. Fast. III, 725 y ss.; Cic. Att. VI.1.12; Aug. Ciu. VII.21; Fest. 76; Catull. LXI.126; Sen. Contr. VII.6). У дні фестивалю римлянам дозволялось говорити будь-які непристойності та

\footnotetext{
3 Clarke J. Looking at Laughter: Humor, Power, and Transgression in Roman Visual Culture, 100 B.C. A.D. 250. Berkeley: University of California Press, 2007. 322 p.

${ }^{4}$ Richlin A. The Garden of Priap sexuality and aggression in roman humor. Oxford: Oxford University Press, 1992. $358 \mathrm{p}$.
} 
співати «саrmina Fescennina» (рід народних сатиричних (іноді вельми вільних) віршів у діалогічній формі). Звісно з огляду на це, сексуальний гумор був важливою складовою святкувань (Mart. IV.14; Juven. VII.91).

Головним персонажем «релігійної непристойності» був Бог плодючості Пріап і присвячена йому комічна збірка «Пріапеї» (Corpus Priapeorum). Його іконографічна особливість - це оголений великий фалос5. Даний атрибут виконував функції комічної прикраси та, що є більш важливим, апотропії (захист від Злого Ока). Місця локацій зображень Пріапа є дуже різноманітними: від інтер'єру приватних жител і садів до таверн і лупанарів. Цікавою для аналізу є комічна фреска «Пріап з подвійним фалосом» (70-79 рр. після Р.Х.), яка розташовувалась на верхньому фризі північної стіни помпейського лупанару (Рис. 1). Ітифалічний бог стоїть на фоні фігового дерева священного символу Давнього Риму (NH. XV.77; Liv. I.4.5; Ovid. Fast. II.411-12; Plut. Rom. III.5-IV.1; Varro. De Ling. Lat. V.54).
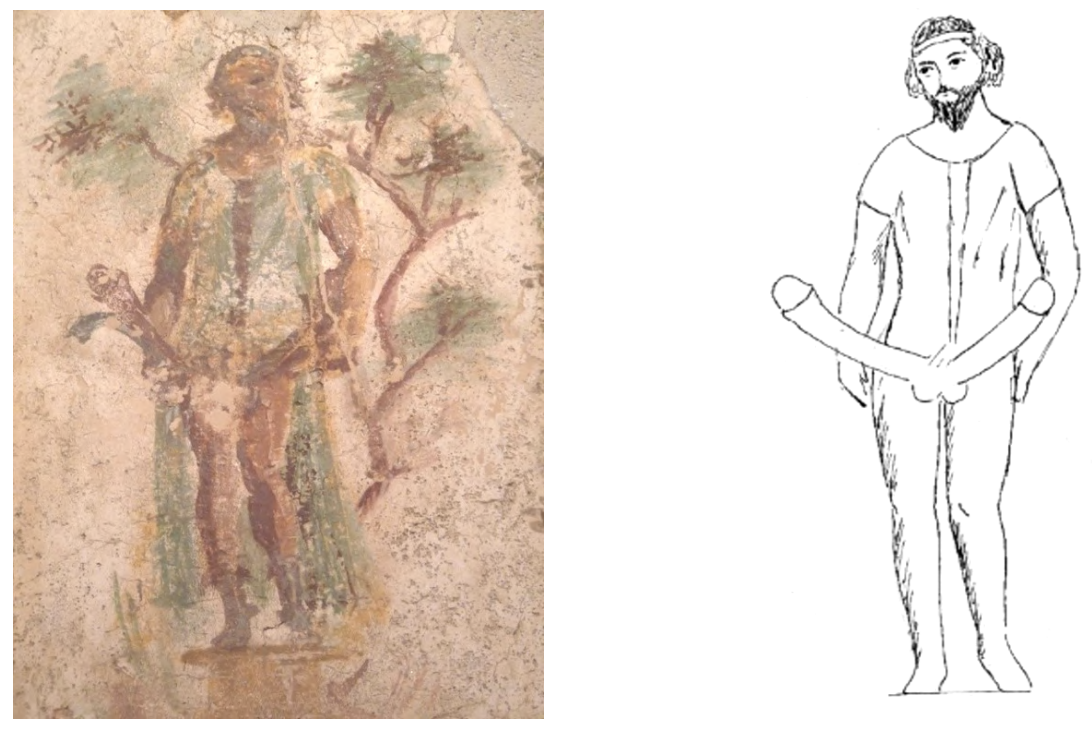

Рuc. 1. Priapus з подвійним фалосом. 70-79 рр. після Р.Х.

(Лупанар, Помпеї. Північна стіна, між кімнатами с і d)

Згідно з міфами, фіга була улюбленим фруктом давньоримських богів: Бахуса (Бог вина) та Церери (Богиня урожаю та плодючості) й представляла жіночу плодючість і привабливістьб. Навіть, якщо згадати випадок з Катоном Старшим (давньоримський політик часів Республіки), коли він подарував сенату жменю свіжої фіги 3 Карфагену, для того, щоб упевнити римлян почати третю Пунічну війну (Plut. Cat. XXVII). Катон використав їі у сатиричному контексті, роблячи натяк на «жіночість» і неспроможність до дій сенату. Саме через це фігове дерево на фресці можна трактувати або як символ плодючості, або ж як комедійний атрибут (адже Пріап зображений надто гіпермаскулінним на фоні жіночих плодів). Спробуємо ж визначити функції, які виконувало це зображення.

\footnotetext{
${ }^{5}$ Halperin D., Winkler J., Zeitlin F. Before Sexuality: The Construction of Erotic Experience in the Ancient Greek World. Princeton: Princeton University Press, 1990. P. 105.

6 Impelluso L. A Guide to Imagery: Nature and Its Symbols. J. Paul Getty Museum, 2004. P. 180.
} 
По-перше, місцем локації є Лупанар, куди люди приходять отримати задоволення, таким чином зображення надає захист і безпеку простору. По-друге, подвійний фалос додає гумористичний ефект, адже за медичними показниками, герой на фресці хворий на дифалію7. Оскільки хвороби статевих органів призводили до чоловічого безсилля та женоподібності, то суворо висміювались римськими авторами (Ovid. Amor. III.7; Pet. Sat. 126ff; NH VII.75; Suet. Aug. LXXXIII). Варто лише згадати чоловіка хворого на гідроцель і фімоз із приміських терм у Помпеях (Рис. 2).

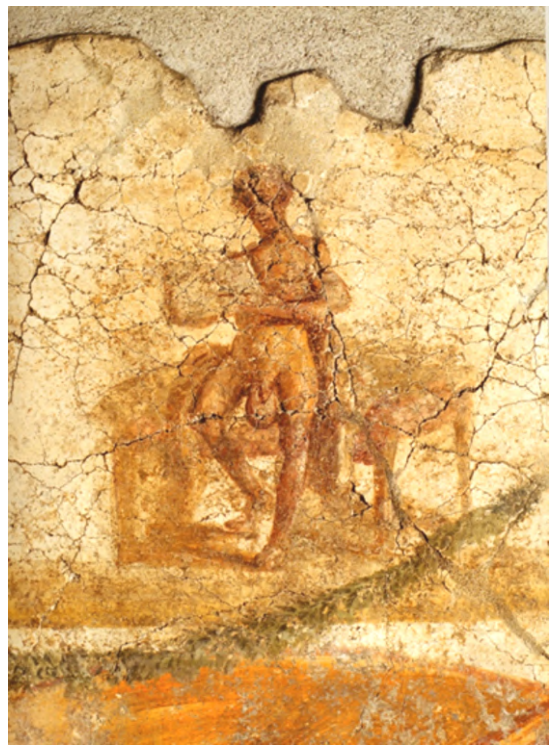

Рис. 2. Чоловік хворий на гідроцель. сцена VIII. 62-79 рр. після Р.X. (Приміські терми, Помпеї)

Потенційна диверсія, яка супроводжувала Пріапа через його статевий орган, - вічне джерело безглуздих веселощів. Апотропічна сила, яку викликав його атрибут, підсилювалась і його зовнішнім виглядом, який виходив за межі загальноприйнятих стандартів римської краси. Відповідно, Пріап був уособленням категорії «Інших», iї божественним «королем». Між тим, варто прослідкувати хто ж входив до категорії «Інші», такої важливої для розуміння римського сміху. Італійський дослідник Доро Леві у візуальному мистецтві відносить до неї «істот, які мають смішну зовнішність з яскраво виділеним статевим органом i звичайних людей, зображених у непристойних діях з вульгарними жестами та мовою»8. Отже це пігмеї, ефіопи, карлики. На нашу думку, варто іï розширити також людьми маргінальних професій, у більшості випадків акторами (мімами, stupidus i т.п.). Саме ці - «Інші», виступають у візуальному сексуальному гуморі основними об'єктами для сміху.

Розглянемо докладніше вищезазначені образи та проаналізуємо чому ж вони змушували римлян сміятись, в яких варіаціях і де були зображені.

У найпершу групу варто виокремити римські жарти пов'язані з іноземцями. 3 кінця I ст. до Р.X. популярним в образотворчому мистецтві Риму стають сюжети в яких фігурують пігмеї й ефіопи. Суттєвий вплив на формування даного іконографічного ряду чинила Давня Греція. Пігмейський народ на римських мозаїках або фресках завжди виглядає неправильно. Всі вони контрастують з ідеалом фізичної краси давніх римлян: від пропорцій тіла до великих розмірів чоловічих статевих органів. Також часто зображуються у девіантних статевих актах - на природі або у човнах9. Моральні підвалини Давнього Риму у вищій мірі підтримували приватність інтимних стосунків, тому нормальні людські пари на зображеннях під час сексу завжди знахо-

\footnotetext{
7 Stevenson R., Hall J. Human Malformations and Related Anomalies. Oxford University Press, 2005. Р. 1264. Дифаллія - вроджена аномалія розвитку сечостатевої системи, що характеризується подвоєнням (повним або частковим) статевого члена.

8 Doro L. The Evil Eye and the Lucky Hunchback // In Antoich-on-the-Orontes. Princeton: Princeton University Press, 1941. P. 225.

9 Versluys M. Aegyptiaca Romana: Nilotic Scenes and the Roman Views Of Egypt. Leiden: Brill, 2002. P. 184, 191.
} 


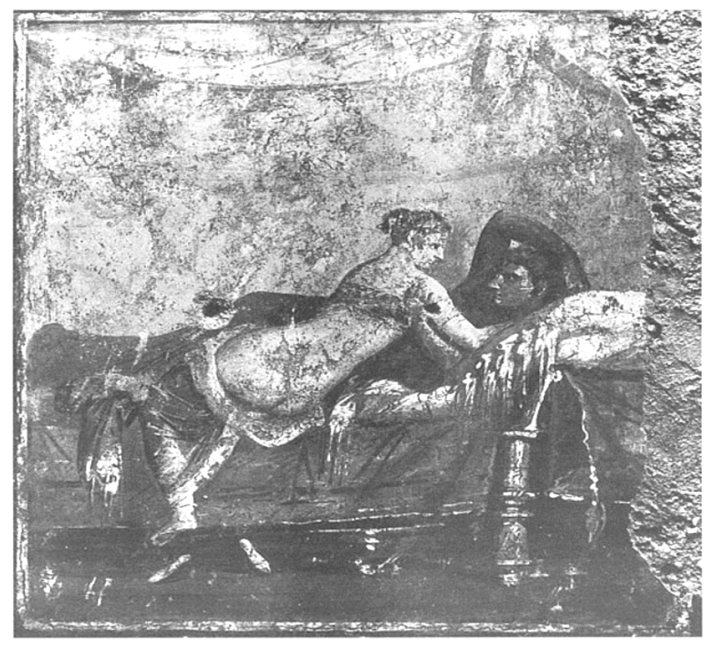

Рис. 3. Пара у ліжку. 40-45 pp. після Р.Х.

(Будинок Прекрасного Імплювія, Помпеї) дяться у спальні, на противагу публічним збоченням «потворних істот» (Рис.3). Даний сюжет 3 пігмеями був популярним серед римлян, відповідно його можна побачити на різних локаціях міст. Більш яскраво представлений він у Помпеях, де в загальному було знайдено близько 17 зображень ${ }^{10}$. Можливо найкращим прикладом багатофункціональності карлика-пігмея $€$ живопис $з$ помпейського Будинку Лікарів.

Істотно важливою для нашого дослідження $\epsilon$ фреска «Бенкетування пігмеїв» (Рис. 4). На ній зображені карлекоподібні істоти, які святкують, у той час як двоє з них поруч, не стидаючись вступають у статевий акт. Отже - це відкрита карикатура на римський сим-

позіум. Значення зображення скоріш за все у тому, щоб вказати на те, що давній римлянин не повинен робити під час convivium (застільного товариства): пити занадто багато алкоголю, танцювати та займатися публічним сексом (Sen. Ep. LXXXIII. 95.1516). Окрім того, девіантна поведінка пігмеїв слугувала приводом для веселощів, а потворність відволікала увагу пристріту на себе.

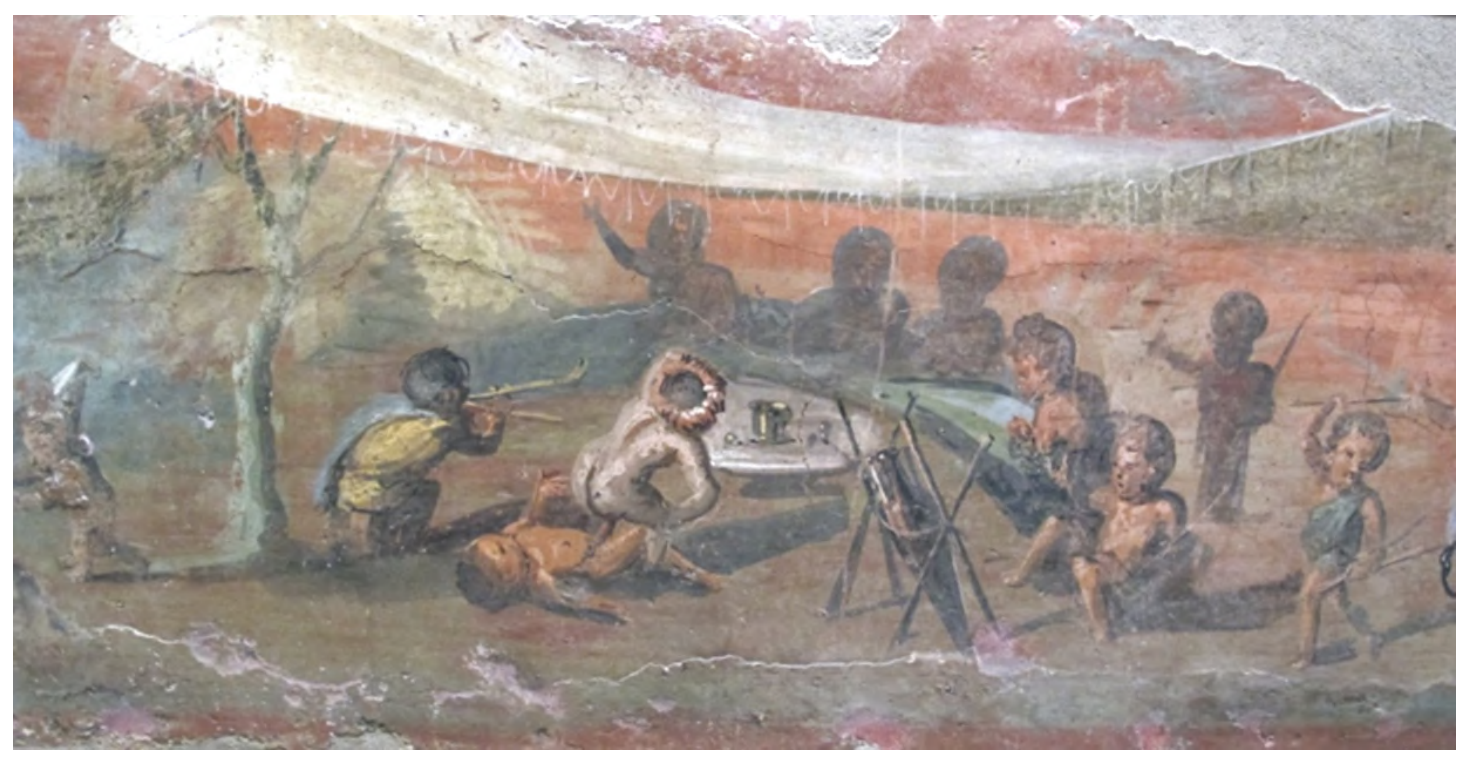

Рис. 4. Банкетування пигмеїв. 45-70 pр. після Р.Х.

(Будинок Лікарів, Помпеї. Національний археологічний музей, Неаполь)

10 Mols S., Moormann E. Ex parvo crevit: Proposta per una lettura iconografica della Tomba di Vestorius Priscus fuori Porta Vesuvio a Pompei // Rivista di Studi Pompeiani. 1993-94. № 6. P. 28. 
Також деякі дослідники підкреслюють соціальне значення комічних зображень пігмеїв, беручи до уваги римську колонізацію Єгипту 31 р. до P.Х.11. Римлянизавойовники, сміючись над ними, відчували себе вище статусом за переможених. Соціальна інтерпретація може також відноситись до деяких еротичних сцен, які іноді з'являються у «нілотських сюжетах» 3 пігмеями як пародія на любовну інтригу. Типовим прикладом $\epsilon$ політична карикатура на роман Клеопатри (остання цариця елліністичного Єгипту з македонської династії Птоломеїв) і Марка Антонія (давньоримський політик) (Рис. 5). Оскільки, за часів Августа, у народному уявленні Антоній став єгипетським монстром, переможеним і сексуально поневоленим аморальною Клеопатрою12.

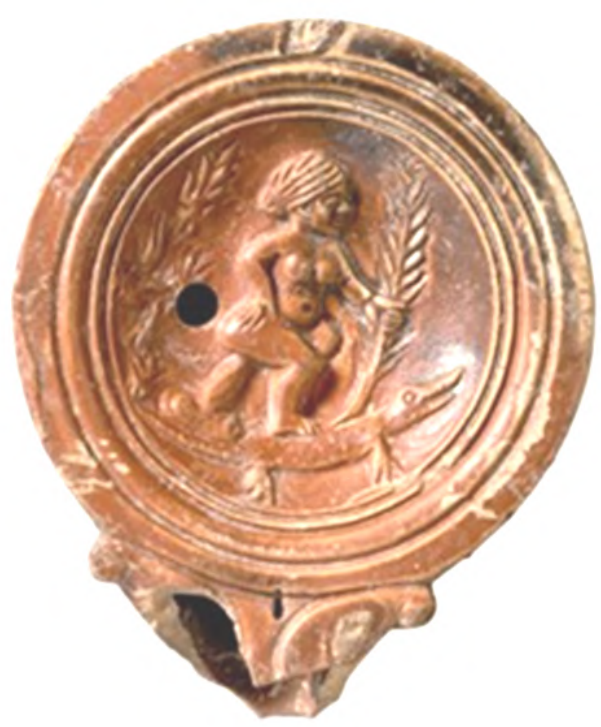

Puc. 5. Римська олійна лампа із зображенням статевого акту жінки та крокодила (політична карикатура «Клеопатра та Антоній») 50-75 рр. після Р.Х.

(Рейнський краєзнавчий музей)

Ефіопів через статус «Інших» людей за межами цивілізованого світу, греко-римські автори також зображали як порушників гендерних норм (Diod. Sic. I.27.1-2, II.21-23, 44-46, III.52-55, V.32.1-7; Hippocrates Aer. 1722; Herodot. Hist. I.105, II.35, VIII.104-106; Strabo. Geogr. III.4.18, IV.4.3, 6; XI.5.1-4). Загалом вони часто асоціювались 3 «жіночими» рисами: страху, розпутності та любові до задоволення ${ }^{13}$. Чорношкірих спостерігаємо й у ролі рабів - повної протилежності елітним маскулінним чоловікам. Більшість візуальних сюжетів з ними обіграні у комедійній формі та знаходяться на мозаїках у термальних комплексах. У цьому контексті, проаналізуємо мозаїку з caldarium (найбільшого приміщення римського банного комплексу з величезною гарячою ванною та підігрітою підлогою) елітного будинку у Тімгаді (Рис. 6).

Художник зображає гіперфалічного ефіопа під час акту сечовипускання або мастурбації (що вважалось доволі комічним, принизливим та огидним для давніх римлян). Самозадоволення порушувало ідеал римського vir $^{14}$, бо воно не вело до продовження роду, навіть філософ Артемідор у своєму соннику пише: «Бачити уві сні рукоблудство позначає поєднання з рабом або рабинею, тому що руки, які керують тілом, ніби його служники. Якщо ж рабів він не має, то це нанесення шкоди через марну трату семен...» (Artemidorus I.78). Також, висміювання вищезазначеного акту $\epsilon$ актуальним й у сатирі як натяк на імпотенцію або пасивність (Mart. II.43.14, XI.104.13-14, XII.46; Lucil. 307-959). Таким чином, фалос ефіопа стає апотропією через перебільшений розмір і девіантний акт самозадоволення. Внаслідок цього, при зображенні цієї іконографічної моделі, увага завжди акцентується на надзвичайно

\footnotetext{
11 Versluys M. Aegyptiaca Romana: Nilotic Scenes and the Roman Views Of Egypt. Leiden: Brill, 2002. P. 285-299.

12 Chauveau M. Cléopâtre au-delà du mythe. Paris: Liana Levi, 1998. P. 144.

13 Thompson L. Romans and Blacks. Norman: University of Oklahoma Press, 1989. P. 161.

14 Справжній римський чоловік, громадянин.
} 
ерегованому статевому органі не задля статевої стимуляції глядачів, а саме в апотропічному/комічному контексті.
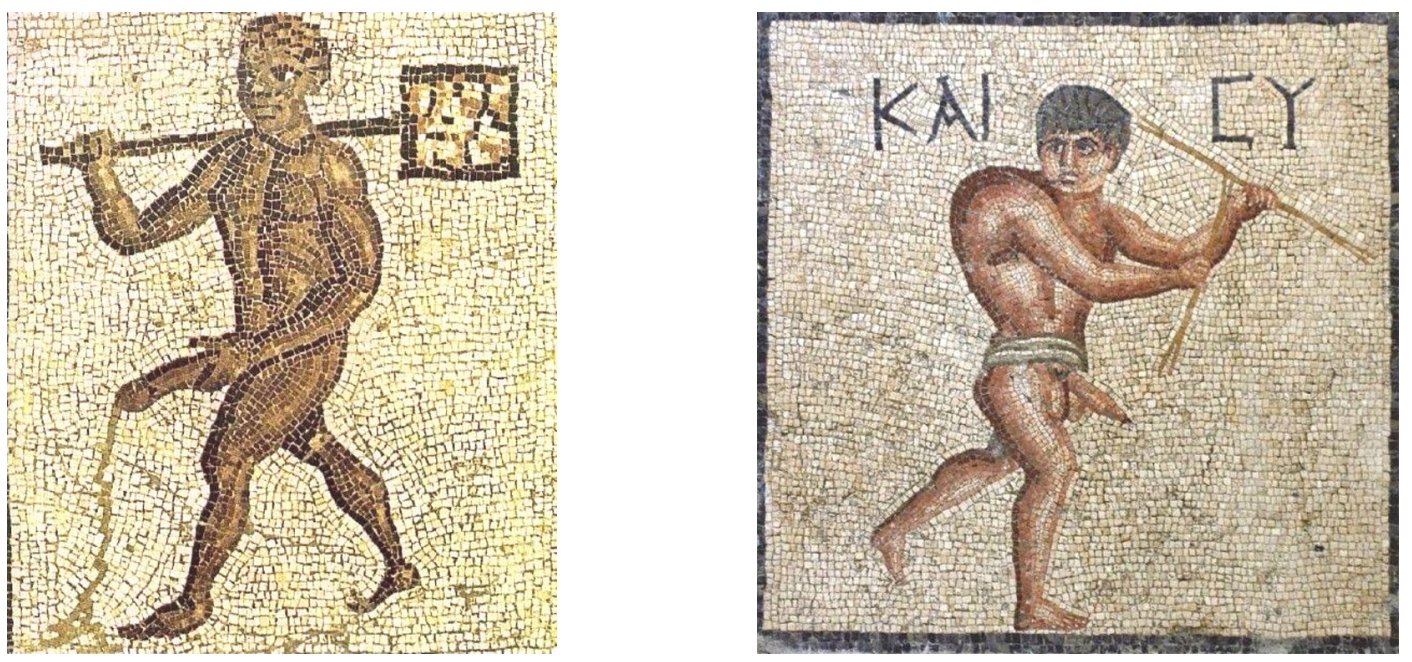

Рис. 6-7. 6 - Ефіоп з вогняною лопатою. 200 р. після Р.Х. (Археологічний музей, Тімгад); 7 - Удачливий горбань. ІІ ст. після Р.Х. (Будинок Злого Ока, Антіохія)

Не менш поширеними образами у давньоримському гуморі є люди з фізичними вадами. Загалом це можуть бути: горбані, каліки або хворі на статеві органи. Вищезазначені «юродиві» доволі часто зберігались в якості рабів або домашніх тварин при імператорських дворах (NH VII.16.75; Alex. Sev. XXXIV.2; Tac. Ann. XII.49.1; Quint. Instit. orat. II.5.10-12.) і публічно демонструвались на бенкетах і суспільних заходах (театр або гладіаторські бої) задля розважання народних мас (Suet. Dom. IV.2.). Римський історик Светоній згадує, що імператор Август з ненавистю ставився до карликів і калік як до «дурного знаку», проте із задоволенням показував їх як забаву (Suet. Aug. LXXXII). Також Пліній Старший розповідає про Юлію Августу, яка мала при собі карлика на ім'я Конопас як домашню тваринку для гри (NH. VII.16.75). Якщо ж звертатись до візуальних джерел, то комічні потвори $є$ не менш популярними. Їх особливість - це потворні риси (деформація тіла) та перебільшений фалічний атрибут (адже на 30 зі збережених зображень горбанів, вони мають аномально великі геніталії) 15 .

Типовою для цього іконографічного типу є мозаїка «Горбань із ритм паличками» з будинку Злого Ока в Антіохії (Рис. 7). На ній ми бачимо везунчика-горбаня, людину, яка хвора на сколіоз і має гіперфалічний статевий орган. Він напівобернутий назад. Напис «kai sy» над ним, з давньогрецької мови позначає «ти також», або «те саме»16. Тобто, «бажаю тобі того ж, що й ти мені». Такого роду напис зустрічається у різних місцях: на підлогах, порогах, стінах, колонадах та інших предметах. Функція цього комічного зображення очевидно апотропічна (відбиття зла чи пристріту). Адже його потворні риси викликають сміх, а напис відганяє темні сили, повертаючи прокляття до людини, яка насилає його.

15 Trentin L. Hunchback in Hellenistic and Roman Art. London; New York: Bloomsbury Academic, 2015. P. 55. 16 Brenk F. The Kai Su Stele in the Fitzwilliam Museum, Cambridge // Zeitschrift für Papyrologie und Epigraphik, 1999. № 126. P. 169-174. 
Окрему групу для гумористичних сюжетів складають люди, які займали девіантні ролі у статевих практиках. Справжню збірку «статевих табу» можна прослідкувати на фресці з Приміських терм із зображенням групової практики (Рис. 8). На ній ми бачимо порушення усіх римських моральних норм, єдиний хто займає прийнятну статеву позицію (fututor, pedico, irrumator ${ }^{17}$ ) - це домінантна постать зліва (vir). За соціально-статевою схемою давніх римлян, він $\epsilon$ елітним чоловіком, який притримується лише «проникаючої ролі»18. Проте, поглянемо на середнього коханця, який приймає анальне проникнення. Це - cinaedus або pathicus, чоловік, який має женоподібну поведінку та при статевому акті займає рецептивну роль (Juven. II; Cic. In Ver. II.2.192; Phaed. Fab. V.1.12-18; Pet. Sat. 21, 23; Mart. X.98; Suet. Aug. LXVIII; CIL IV. 1825, 2319b, 4917; Priap. LXIV.1-2). Катулл у своїй 16 поемі принижує такими термінами якихось своїх супротивників - Аврелія та Фурія: «Aureli pathice et cinaede Furi», погрожуючи їм проникнути у них анально й орально (Catull. XVI).

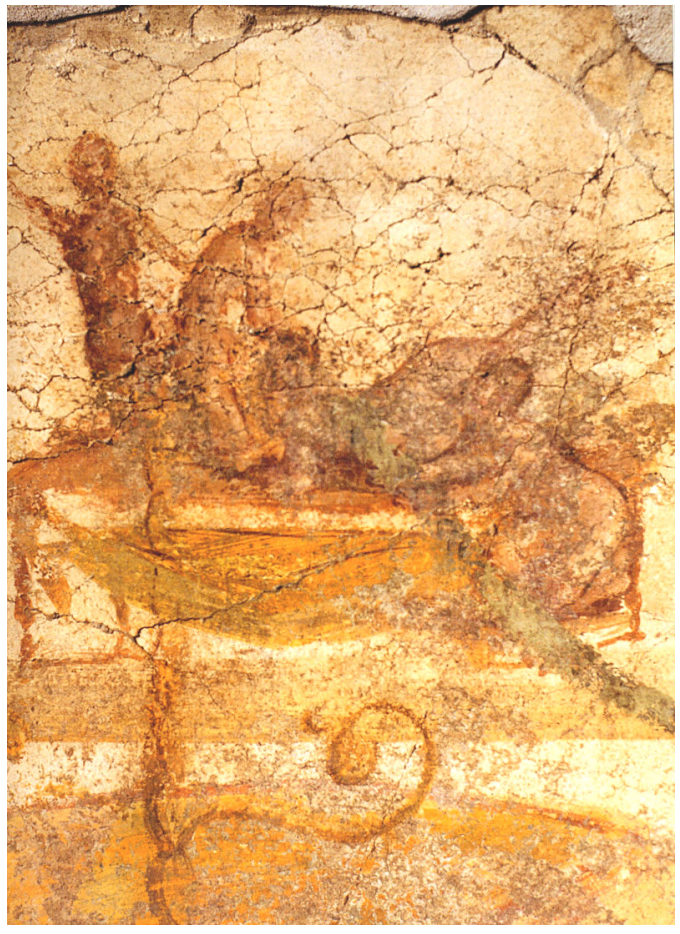

Рис. 8. Статева групова практика. Сцена VII. 6279 pр. після Р.Х. (Приміські терми, Помпеї)

Жарти на рахунок чоловіків, яким подобалось бути проникнутими, пронизують всю римську сатиру та епіграму (Mart. I.65, II.51, II.54, II.62, III.71, III.95, IV.48, VH.52, VI.37, VI.54, VII.58, 11.88; Juven. II.9). Приниження мужності вважалось смішним та образливим, тому звинувачення у женоподібності було частим сюжетом ораторських промов у суді також (Cic. Sest. XVIII) ${ }^{19}$. Поряд з cinaedus на фресці чоловікоподібні жінки, які вступають в одностатевий сексуальний акт. Латинський словник визначає такого роду жіночу особу як tribas, fricatrix ${ }^{20}$. Опис народження цього явища - у гумористичній формі, ми бачимо у байці Федра (Phaedr. Fabl.VI.16). Зовнішній вигляд tribas завжди описується авторами як потворний і чоловікоподібний (Luc. Dial. Courtes. V).

Типовим прикладом даного феномену $\epsilon$ образ Філеніди Марціала. У його епіграмах вона зображується як «анти-жінка»: вживає багато вина, веде розпутне життя, займається неприйнятними сексуальними практиками та має гіперсексуальні бажання, що повністю порушують pudicitia набір моральних якостей, який властивий порядній жінці римського суспільства (Mart. VII.67, VII.70). До того ж вони виконують дві найбільш неприйнятні статеві

\footnotetext{
${ }^{17}$ Активний у статевому акті чоловік.

18 Williams C. Roman Homosexuality: Ideologies of Masculinity in Classical Antiquity. Oxford: Oxford University Press, 1999. P. 258.

${ }^{19}$ Corbeill A. Controlling Laughter: Political Humor in the Late Roman Republic. Princeton: Princeton University Press, 1996. P. 44.

20 Жінка, що надає перевагу сексу з іншою жінкою.
} 
практики для римського суспільства - кунілінгус і феляцію (Ovid. Ars Am. III.770-788; Mart. II.84, III.96, XI.40; Priap. LXXVII; CIL. IV,8898). Їх задоволення паплюжать ритуал соціальних обіймів і поцілунків, за допомогою яких регулювались римські владні стосунки (від імператора і до низів) (Mart. XI.61, XI.85, XII.85, XIV.69; Catull. XVI). Отже, ця гумористична фреска презентує справді набір девіантних сюжетів $з$ повністю перевернутими соціальними ролями.

Менш складний серійний сексуальний гумор такого типу з'являється на медальйонах до теракотового посуду долини Рон у Франції21. Художники-керамісти, копіюючи перевірені часом сексуальні композиції, вигадували й нові позиції та комбінації коханців. Найцікавіше, що вони створили серію сексуальних сцен із підписами. Деякі з них коментують зображену сцену, інші вкладають слова у вуста головних героїв - часто одностопні анекдоти. Більшість гумористичних сюжетів грунтується на тому, що жінка під час статевого акту «отримує верх», або «перемогу».

Звернемо увагу на медальйон знайдений у 1951 р. недалеко від Арля із зображенням жінки, яка тримає у руці щит і меч її партнера. Підпис «orte scutus est» («Бережись! Це щит!») (Рис. 9). Художник використав класичний комічний хід - зміни ролей, він змусив жінку взяти на себе чоловічу зброю. Чоловік показаний безсилим (з відсутньою ерекцією) на «битві кохання». Інший медальйон цього типу представляє вінчання жінки лавровим вінком і надпис «tu sola nica» («Ти єдиний переможець!») (Рис. 10). «Перевернуті сюжети» викликали сміх у римлян, адже у реальному житті, жінка не могла й подумати про панівну роль. Римський народ сміявся над женоподібністю чоловіків і чоловічими рисами жінок, як і на фресці з Помпейських терм.

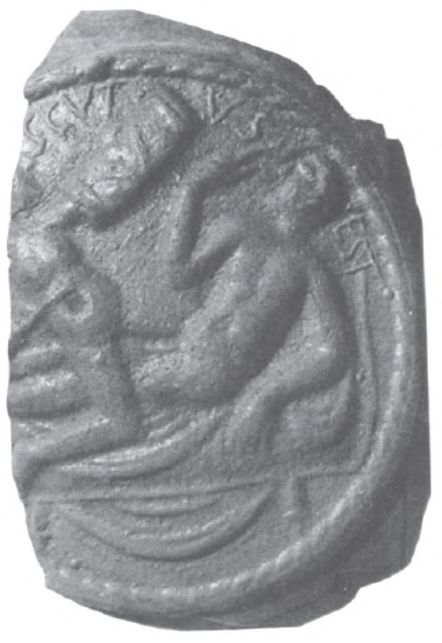

Рuc. 9. Статева практика Venus pendula, mulier equitans, agitare equum, vehere equo з написом «orte scutus est». II cт. після Р.X., теракотовий медальйон.

(Арль, Лапідарій Національний музей)

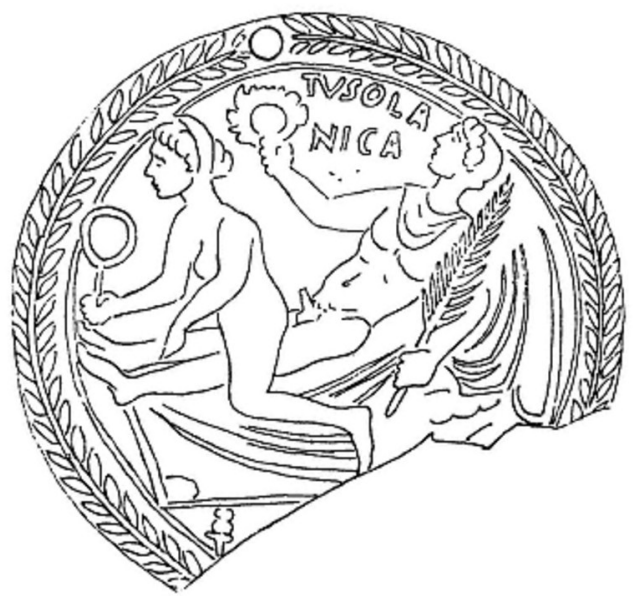

Puc. 10. Статева практика Venus pendula aversa 3 написом «tu sola nica», теракотовий медальйон. (Долина Рон)

Вищезгадані сюжети й образи знайшли свій відбиток також у театральних видовищах і розвагах. Популярними у Давньому Римі були міми, під час яких часто вико-

\footnotetext{
${ }^{21}$ Bailey D. A catalogue of the lamps in the British Museum Roman provincial lamps. London: British Museum, 1988. 560 p.
} 
нувались справжні статеві акти²2. Якщо спочатку, це були дійства вшановуючи культ плодючості, то до ІІ ст. до Р.Х. вони переросли у масштабні театральні дійства (Macrob. Sat. I.14.9; Tac. Ann II.49.1; Ovid. Fast. IV.946; V.183; V.347-348; Sen. Ep. XCVII.8; Auson. Ecl. XVI.25-6; August. Civ. Dei II.27; Cons. ev. I.33.51; Ep. XCI.5; Arn. Adv. nat. III.23.3; Lactant. Div. inst. I.20.10; Tert. De spect. XVII.3). Багато латинських авторів, зокрема Baлерій Максим і Марціал, розповідають наочну історію про те, як Катон, вірний прибічник старих республіканських цінностей, завжди виходив з театру перед Nudatio mimarum під час Флоралій (Val. Max. II.10.8; Mart. I).

Одна з картин Таверни на вулиці Меркурія має особливо театральний колорит (Рис. 11) ${ }^{23}$. Ми бачимо жінку, яка тримає у руках кухоль з вином, і водночас чоловіка, який намагається проникнути у неї анально, скориставшись ситуацією. Що викликало сміх у цьому видовищі? По-перше - це те, що жінка п'є вино (Gell. Noct. Attic. X.23; Val. Max. Facta et dicta memor. VI.3.9; Mart. I.87.1-2) (матронам було заборонено вживати алкогольні напої). По-друге, публічність видовища й анальне проникнення, яке зазвичай не використовувалось до жінок вищого стану, тобто матрон. Знову ж таки, ми бачимо гумористичну зміну соціально-статевих ролей.

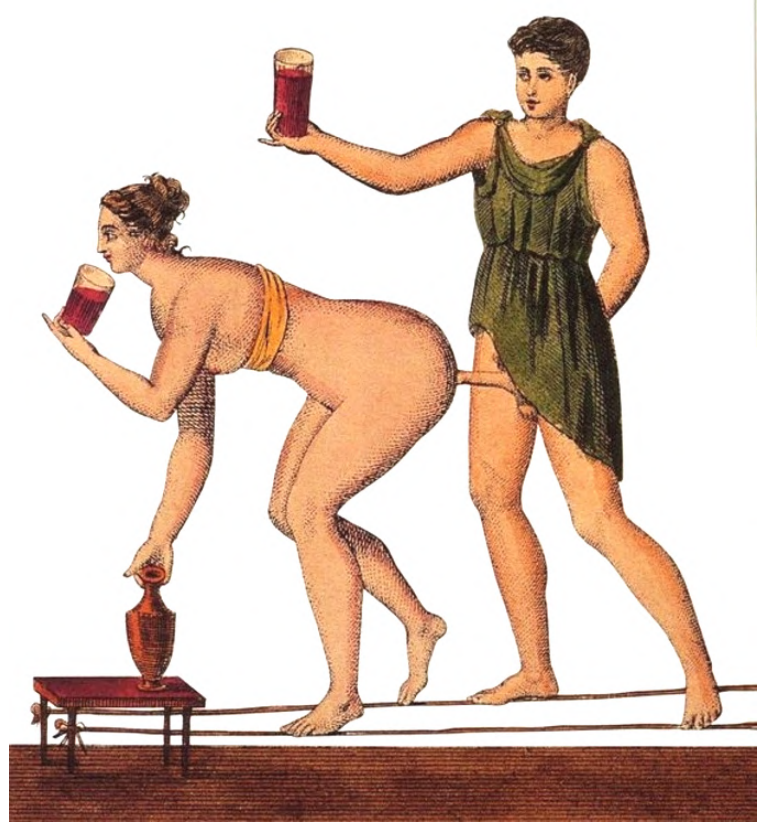

Puc. 11. Сексуальна акробатика. 62-79 рр. після Р.Х., Таверна на вулиці Меркурія, Помпеї

(Louis Barré, Herculanum et Pompéi, le musée secret; Paris, 1839)

Отже, ми з впевненістю можемо стверджувати, що у більшості комічних сюжетів превалюють маргінальні образи та дії: іноземні (пігмеї, ефіопи), або потворні збочені істоти (карлики, горбані й ін.) і девіантні ролі у статевих актах (активні жінки, пасивні чоловіки, виконання оральних практик). В основі популяризації такого роду мистецтва прихований ключ до регулювання моральноетичних норм встановлених у Давньому Римі. Оскільки соціальна роль римлянина визначалась і таким питанням, як те: «Над чим ти смієшся?». Римський громадянин, визнаючи дії на зображенні девіантними, повинен був сміятись над ними, доходячи висновку, що така поведінка табу. Головну функцію жартів можна визначити як апотропічну/релігійну, що бачимо з більшості вище проаналізованих сюжетів. В обрядах і фестивалях гумор слугував контрапунктом до урочистої релігійної функції.

Ряд традицій, які починались як апотропні, з часом трансформувались, щоб прийняти гумористичний аспект. Місця локацій гумористичних візуальних сюжетів різноманітні: від приватних і суспільних місць до керамічних виробів.

\footnotetext{
22 Richter G. Grotesques and the Mime // American Journal of Archaeology. 1913. № 17. P. 153.

${ }^{23}$ Famin C. Musée Royal de Naples: Peintures, bronzes et statues érotiques du Cabinet Secret, avec leur explication. Paris, 1836. P. 90-91.
} 


\section{REFERENCES}

Bailey, D. (1988). A catalogue of the lamps in the British Museum Roman provincial lamps. London: British Museum.

Beard, M. (2014). Laughter in Ancient Rome: On Joking, Tickling, and Cracking. Berkeley; Los Angeles; London: University of California Press.

Brenk, F. (1999). The Kai Su Stele in the Fitzwilliam Museum. Zeitschrift für Papyrologie und Epigraphik, 126, 169-174 [in German].

Chauveau, M. (1998). Cléopâtre au-delà du mythe. Paris: Liana Levi [in French].

Clarke, J. (2007). Looking at Laughter: Humor, Power, and Transgression in Roman Visual Culture, 100 B.C. - A.D. 250. Berkeley: University of California Press.

Corbeill, A. (1996). Controlling Laughter: Political Humor in the Late Roman Republic. Princeton: Princeton University Press.

Famin, C. (1836). Musée Royal de Naples: Peintures, bronzes et statues érotiques du Cabinet Secret, avec leur explication. Paris [in French].

Halperin, D., Winkler, J., \& Zeitlin, F. (1990). Before Sexuality: The Construction of Erotic Experience in the Ancient Greek World. Princeton: Princeton University Press.

Impelluso, L. (2004). A Guide to Imagery: Nature and Its Symbols. J. Paul Getty Museum.

Laurent, M., Versluys, J., \& Meyboom, P. (2006). Nile into Tiber. Egypt in the Roman World. Leiden: Brill.

Levi, D. (1941). The Evil Eye and the Lucky Hunchback. In Antioch-on-the-Orontes, vol. III (pp. 220-232) Princeton: Princeton University Press.

Mols, S., \& Moormann, E. (1993-94). Ex parvo crevit: Proposta per una lettura iconografica della Tomba di Vestorius Priscus fuori Porta Vesuvio a Pompei. Rivista di Studi Pompeiani, 6, 15-52 [in Italian].

Richlin, A. (1992). The Garden of Priap sexuality and aggression in roman humor. Oxford: Oxford University Press.

Richter, G. (1913). Grotesques and the Mime. American Journal of Archaeology, 17, 149-56.

Stevenson, R., \& Hall, J. (2005). Human Malformations and Related Anomalies. Oxford University Press.

Thompson, L. (1989). Romans and Blacks. Norman: University of Oklahoma Press.

Trentin, L. (2015). Hunchback in Hellenistic and Roman Art. London; New York: Bloomsbury Academic.

Versluys, M. (2002). Aegyptiaca Romana: Nilotic Scenes and the Roman Views of Egypt. Leiden: Brill.

Williams, C. (1999). Roman Homosexuality: Ideologies of Masculinity in Classical Antiquity. Oxford: Oxford University Press.

\section{Yevheniia Fedchenko}

(Taras Shevchenko National University of Kyiv, Kyiv, Ukraine)

ORCID: https://orcid.org/0000-0001-9050-3338

\section{Sexuality and Humor in Ancient Rome: Rethinking and New Variations}

Sexual humor has always been one of the most important subjects of philosophical, aesthetic and historical studying. Its forms and interaction with a wide range of problems have been raised by researchers and artists of different times. Ancient Romans were not an exception, and paid special attention to erotic jokes, giving them a specific colouring.

The goal of this paper is to define comprehensively the role and place of sexual humor in the life of Ancient Rome. To achieve the mentioned goal, the author applies the analysis of written and visual Roman humor from pun to various forms of public entertainment. The features of the storyline and the personalities of Ancient Roman sexual humor are analyzed; the central functions of obscene Roman jokes are revealed; the attitude of the Romans to laughter and its influence on the formation of public opinion is cleared up; the location of humorous sexual images in Ancient Rome is retraced. The source base shows that most comic plots included marginal images and actions: ugly and perverted creatures (hermaphrodite, pygmy, fool, black-skinned, slaves) and deviant sexual acts (woman with a woman, active women, and passive men). It is worth noting that particularly popular were the «inverted sexual stories», where a woman changed roles with a man. The Roman people laughed at the femininity of men and the masculine features of women. With the help of gained materials, it is possible to 
retrace how that art form became a «hidden key» in regulating of moral and ethical norms established in the society of Ancient Rome. One of the questions determining the social role of the Roman was: «What are you laughing at?» A Roman citizen, recognizing actions in the image as deviant, had to laugh at them, concluding that such behavior was taboo.

A detailed analysis of the problems of gender stereotypes refuting in ancient Roman comic plots is also conducted. This opens up a new reading of the matter and helps to find out the interaction between gender identity and social status.

Keywords: Ancient Rome, sexuality, humor, daily life, gender 